\title{
Breast Phyllodes Tumor
}

National Cancer Institute

\section{Source}

National Cancer Institute. Breast Phyllodes Tumor. NCI Thesaurus. Code C7575.

A benign, malignant, or borderline circumscribed biphasic neoplasm that arises from the breast. It usually affects middle-aged women. It is characterized by the presence of a double layer of epithelial cells that are arranged in clefts, surrounded by a spindle cell mesenchymal (stromal) component. 